\title{
Organizational listening: Addressing a major gap in public relations theory and practice
}

\author{
Jim Macnamara \\ University of Technology Sydney
}

\begin{abstract}
An extensive body of literature theorizes public relations as two-way communication, dialogue, and relationships between organizations and their publics. While there are alternative views including public relations as advocacy, most theories emphasize dialogue, co-orientation, and relationships incorporating satisfaction, trust, and control mutuality - even to the extent of symmetry. Critical perspectives propose a 'sociocultural turn' that further emphasizes stakeholders' and societal interests. This analysis draws on a three-country study that reveals a major theory-practice gap and proposes a significant expansion of public relations theory in relation to listening to realize normative notions of public relations and give effect to claims of dialogue and engagement.
\end{abstract}

Keywords: Two-way communication, dialogue, speaking, listening, engagement, relationships

\section{Introduction}

This analysis is based on a two-year, three-country research project examining organizational listening among government, corporate, non-government (NGO), and non-profit organizations. The Organizational Listening Project is a transdisciplinary study exploring how and how well organizations listen through a range of practices including audience, stakeholder and social research; customer relations; social media; and public consultation; as well as public relations and corporate, government, political, organizational, and marketing communication. The research project involved an extensive literature review and in-depth analysis of 36 case studies. This article reports and critically analyzes findings specifically in relation to public relations and the practices of strategic communication, communication management, and corporate communication, which are used in Europe and a number of other markets as largely synonymous with public relations (Aarts \& Van Woerkum, 2008); Cornelissen, 2011; van Ruler \& Verčič, 2005).

\section{Key concepts and principles of dominant and alternative theories of public relations}

While some argue that public relations is predominantly advocacy and persuasion on behalf of organizations or individual clients (Bowen, 2008; Porter, 2010), a substantial and growing body of literature identifies at least seven other major theoretical frameworks or approaches. These have been expounded, reviewed, and critiqued by many authors and, therefore, will not be discussed in any detail here. What is relevant and necessary to provide the context for this analysis of research findings is noting the key concepts and principles that underpin and characterize dominant and alternative theories of public relations, including some that are common to several or all approaches. A review of public relations scholarly literature reveals that, along with continuing discussion of advocacy and persuasion, public relations is theorized within the frameworks of: 
- Excellence theory;

- Relationship management;

- Strategic communication;

- $\quad$ Rhetorical theory of public relations;

- Dialogic theory of public relations;

- Engagement; and

- Sociocultural theories of public relations.

These bodies of theory, as well as definitions of public relations of which there are almost 500 according to Harlow (1976), emphasize at least five core concepts and principles of public relations practice that are briefly summarized as the theoretical framework of this analysis.

\section{Two-way communication}

The two most enduring of the original 'four models' of public relations (Grunig \& Hunt, 1984) and Excellence theory, which has been described as the "dominant paradigm" of public relations (L’Etang, 2008; Pieczka, 1996, 2006; Spicer, 2007), emphasize two-way interaction between organizations and their publics. This is explicitly expressed in the two-way asymmetrical and particularly the two-way symmetrical model of public relations, which have evolved and morphed through a number of iterations, but remain central to Excellence theory (L. Grunig, J. Grunig, \& Dozier, 2002; J. Grunig, L. Grunig, \& Dozier, 2006). During its 30 years of development, Excellence theory has incorporated (or appropriated) Murphy's (1991) mixed-motive model, Grunig's situational theory of publics (Grunig, 1997; Grunig \& Hunt, 1984), and elements of contingency theory proposed by Cameron (1997; Wilcox \& Cameron, 2010), as well as several other mid-range theories. But it steadfastly advocates two-way interaction in organization-public relationships (OPR) including co-orientation (Broom, 1977).

\section{Relationships}

As early as the first edition of Cutlip and Center's (1952) PR text, the establishment and maintenance of relationships have been highlighted as a focus of public relations. This has been emphasized since by Ferguson (1984), Center and Jackson (1995), Hon and Grunig (1999), Ledingham and Bruning (1998, 2000), and incorporated into Excellence theory (Grunig et al., 2002). Hon and Grunig (1999) identified control mutuality as one of four key elements of relationships - an acceptance by the parties in a relationship that each should be able to influence the other. Broom says relationships between organizations and their publics should be "mutually beneficial" (2009, p. 7) and Sriramesh claims that public relations creates and maintains "symbiotic relationships" (2009, p. xxxiii). While the term 'relationship management' is questioned by critical scholars such as Fawkes (2015, p. 205), who says it reflects an organizationcentric focus, building and maintaining relationships with stakeholders and publics is widely identified as a core function and rationale of public relations today.

\section{Dialogue}

While dialogue is claimed to be implicit in Excellence theory and is mentioned in relationship theory and rhetorical theory of public relations, Kent and Taylor (2002) have expanded and emphasized this approach drawing on the foundational communication theories of Gadamer (1989), particularly his definition of openness to the other; dialogism as proposed by Bakhtin (1981, 1984); and Buber's notion of $I /$ thou versus I/it interaction and his discussions of monologue, 'monologue disguised as dialogue', and dialogue (Buber, 1958, 2002). An important point made 
by Taylor and Kent (2014) is that dialogue and dialogic are not the same thing. They point out that, while dialogue refers to a specific instance of two-way discussion, dialogic thinking is a broader philosophical stance informing a procedural approach to create an open interactive communication environment in which the views and interests of others are recognized and respected. They say dialogic thinking precedes actual dialogue and should permeate public relations work (p. 390).

In advocating rhetorical theory of public relations, Heath (2001, 2006, 2007, 2009) notes that rhetoric can be categorized as manipulative or invitational and, like communication scholars such as Foss and Griffin (1995), he advocates an invitational approach that he says is ethical and ultimately more effective than one-way attempts at persuasion. Heath (2007) acknowledges that rhetoric includes advocacy, but states that "advocacy is a two-way street" in the rhetorical tradition (p. 47), allowing and even inviting "counter-advocacy" (p. 51). The nature of dialogue and twoway communication are further discussed in the following sections of this analysis.

\section{Engagement}

In 2014 Kim Johnston noted that "engagement has been heralded as a new paradigm for public relations in the 21st century" (2014, p. 381) and a special issue of Journal of Public Relations Research was devoted to 'public relations and engagement' (Vol. 26, No 5). Notwithstanding some insightful analysis by Kang (2014) and a review of dialogic theory of public relations by Taylor and Kent (2014), Devin and Lane noted that “engagement remains under-theorized” (2014, p. 437). However, organizational psychology literature informs us that, as well as involving cognitive processing of information, affective commitment (e.g., a sense of belonging and feeling valued), and positive affectivity (a deeper level of emotional commitment such as absorption, excitement, pride, or passion), engagement requires empowerment, which psychologists and political scientists say is most effectively achieved through participation of some kind (Erickson, 2008; Macey \& Schneider, 2008; Rhoades, Eisenberger, \& Armeli, 2001).

In an intra-organizational context, Bimber, Flanagin and Stohl (2012) define engagement as "how much people perceive that they are able to shape the agenda and the direction of their organization" (p. 32). Drawing on Heath (2006), Taylor and Kent (2014) describe engagement in a public relations context as:

... a two-way, relational, give-and-take between organizations and stakeholders/publics with the intended goal of (a) improving understanding among interactants; (b) making decisions that benefit all parties involved, not simply the organization; and (c) fostering a fully functioning society. (2014, p. 391)

\section{Co-orientation}

While critical scholars have challenged much established public relations theory as functionalist (e.g., Edwards, 2012) and organization-centric in that it is linked to liberal management theory in which "concern for publics is designed to facilitate alignment with management goals" (Fawkes, 2015, p. 205), the preceding discussions of relationships, dialogue, and engagement show that coorientation is fundamental in public relations theory. That is, an organization should orientate towards the views and interests of its publics as well as seek to orientate publics to the views and interests of the organization.

Strategic communication, which is used both as a term in public relations literature (Freeman, 1984; Grunig et al., 2002) and also as an alternative conceptualization and theorization of related 
practices in a number of countries (Aarts, 2009; Aarts \& Van Woerkum, 2008) along with communication management (van Ruler \& Verčič, 2005), provides an example of this theoretical focus on co-orientation. Hallahan, Holtzhausen, van Ruler, Verčič, and Sriramesh (2007) note narrow organization-centric understandings of the term, but argue that "alternative and more positive notions of strategy have ... emerged” based on two-way symmetrical models of public relations (p. 27). They, as well as Cornelissen (2011) in his recent writing on corporate communication, say that strategic communication is balancing the interests of an organization and its stakeholders and publics. It is argued that this is being, or can be, achieved through new approaches to strategy such as emergent communication strategy (King, 2010), participatory strategy (Falkheimer \& Heide, 2011), and what Murphy (2011) calls networked strategy.

While corporate communication has been defined as "the corporation's voice” (Argenti \& Forman, 2002, p. 4) and Cornelissen (2004) originally conceptualized corporate communication and public relations as distinctly separate and different functions, the fields of practice have substantially merged or at least overlapped. Cornelissen subsequently recognized 'corporate public relations' and 'marketing public relations' as integral elements of corporate communication, and his later theorizing describes corporate communication in very similar terms to public relations. Significantly, in recent theorization of corporate communication, Cornelissen describes the field of practice as being about "balancing the mission and vision of the organization" with its environment and about interaction, engagement, and adaptation (2011, p. 83).

This focus on considering the views and interests of stakeholders and publics is most evident in what some identify as a 'sociocultural turn' in public relations. Curtin and Gaither (2005) first proposed a reflexive and dynamic cultural studies approach in public relations. More recently Edwards and Hodges (2011) have claimed that there is "a shift in the ontological and epistemological focus of the field" from its location in strategic organization management mainly in the service of elites to a sociological and cultural context, and from functionalism and behaviorism to social interaction and more humanistic understandings of the world based on social theory (p. 3).

At the risk of going over old ground, this summary is important to highlight that, despite some "historical dissensus in the field about what the practice is, who it serves, and what its roles and responsibilities are” (Berger, 2007, p. 228), public relations is extensively theorized as involving two-way communication, dialogue, engagement, and relationships between organizations and their stakeholders and publics undertaken in a spirit of mutuality if not symmetry. Even rhetoric and strategic communication that have been viewed pejoratively in other literature are presented in rehabilitated form as an ethical approach involving two-way interaction and mutuality. Only advocacy and persuasion retain traces of the press agentry and one-way information processing models identified in a historical context by Grunig and Hunt (1984).

\section{The tautology of two-way communication - it takes 'two to tango'}

While the practice of public relations involves a range of management activities such as budgeting and reporting as well as communication as noted by Budd (1995), its major theories and models and those of corporate communication are fundamentally informed by and, to a significant extent, derivative of human communication theories. Openness to the other (Gadamer, 1989), the principles of dialogue set out by Bakhtin $(1981,1984)$ and Buber $(1958,2002)$, and more recent sociological and sociocultural theories such as those of Dewey $(1916,1927)$ and Carey 
(1989/2009) have led to rejection of transmissional notions of communication (Berlo, 1960; Shannon \& Weaver, 1949) and to understanding of communication as a transactional process involving interaction and shared meaning making (Craig, 1999; Craig \& Muller, 2007; Littlejohn \& Foss, 2008). In fact, it can be argued that the commonly used term 'two-way communication' is a tautology and that, theoretically, there is no such thing as one-way communication - although practice lags, as this study shows.

Furthermore, relationships are, by nature, two-way interactions and exchanges grounded in reciprocity and dialogue (Baxter, 2011). It is an oxymoron to refer to a one-way relationship. Dialogue by definition is two-way, being derived from the Greek prefix di meaning two and the Greek preposition diá meaning 'between', 'through', or 'across'. Equally, despite a lack of theorization of how it is produced and maintained, engagement intrinsically relates to two or more participants.

\section{The communicative corollary of speaking - listening}

Specifically, and here is where we come to the focus of this research study, communication in its recommended two-way form as dialogue must involve speaking and listening (Craig, 2006, p. 39). ${ }^{1}$ Dialogue is more than a single utterance and also more than turn-taking at speaking, and it is reasonable to assume that two-way communication is to be interpreted similarly. In her analysis of dialogue and relationships, Baxter says that a "change of speaking subjects" does not constitute dialogue (2011, p. 49). Dialogue is comprised of an utterance chain in which a series of utterances need to be linked by listening. Recently, many authors have noted the fundamental importance of listening in public communication. For instance, in Listening Publics, Lacey says "without a listener, speech is nothing but noise in the ether" (2013, p. 166). In the context of democratic politics and representation, Downing (2007) notes that there is no point in having a right to free speech if no one is listening. Dryzek goes further and says that "the most effective and insidious way to silence others in politics is a refusal to listen” (2000, p. 149).

Voice is widely used as a metaphor for representation and communication and is cited as a human right (Husband, 1996, 2009; Penman \& Turnbull, 2012); as an essential element of relationships (Baxter, 2011); as the foundation of democracy, which is based on vox populi - the voice of the people (Fishkin, 1995; Green, 2010); and as a necessity for social equity (Couldry, 2010). Couldry describes voice as "the implicitly linked practices of speaking and listening" (2009, p. 580).

However, an extensive transdisciplinary literature review conducted as the first stage of The Organizational Listening Project revealed that communication and voice are predominantly associated with speaking and that there is comparatively little attention paid to its vital corollary listening. Listening theorist Michael Purdy (2004) notes that there has been only a small amount of qualitative research in relation to listening per se and that this is primarily grounded in cognitive psychology, mostly with a therapeutic focus. Lipari (2010) acknowledges that listening is studied in "humanities-based communication scholarship" as well as in "social science and cognitive science literature," but that this is predominantly in the context of interpersonal listening (p. 351).

Bickford (1996) pointed out this gap in the context of politics and the public sphere in her landmark text The Dissonance of Democracy: Listening, Conflict and Citizenship in which she criticized the lack of attention to listening - a cause recently taken up by Dobson (2014) in Listening for Democracy. Dobson says "honourable exceptions aside, virtually no attention has been paid to 
listening in mainstream political science". He adds that efforts to improve democracy have mainly focused on "getting more people to speak" (2014, p. 36). But, as Calder (2011) points out, the real problem in democratic politics is not being denied a voice; it is being denied an audience.

In his sociological analysis, Couldry refers to the paradox "that voice can apparently be offered, without any attention to whether it is matched by processes for listening" and describes this as "part of the banal oxymoron of neoliberal democracy" (2009, p. 581). In Why Voice Matters, Couldry (2010) again observes that "surprisingly, little attention has been given to what listening involves" (p. 146). Dreher (2008, 2009) highlights this in her analysis of marginalized communities. For instance, in discussing Muslims living in Australia, she reported that there is no shortage of articulate spokespersons and commentators within the Muslim community. The challenge faced by Muslims in this predominantly Christian country is "being heard" (2008, p. 7).

Lacey notes that "listening has long been overlooked in studies of the media as well as in conceptualizations of the public sphere" (2013, p. 3). Even in the age of Web 2.0 and interactive social media that offer increased potential for two-way communicative interaction, Crawford concludes that “'speaking up' has become the dominant metaphor for participation in online spaces" and "listening is not a common metaphor for online activity" (2009, p. 526). Furthermore, analysis shows that there is scant attention paid to listening in business and management literature other than discussion of interpersonal listening in an intra-organizational context (e.g., in human resources management), as noted by Flynn, Valikoski, and Grau (2008).

Before leaving the broad transdisciplinary terrain of political, sociological, and humanities literature to focus on public relations, two further points of discussion are noteworthy and necessary. First, it is essential to define what is meant by listening. Second, it is important to contextualize listening in relation to organization-public relationships (OPR), as opposed to other analyses that focus on interpersonal communication or therapeutic applications.

\section{Defining listening}

In examining organizational listening it is important to have a realistic as well as a clear definition of what this process might entail. If we set unrealistically high expectations, listening is bound to fall short. On the other hand, it is important to recognize that, as well as non-listening, there are many forms of fake listening such as pretend listening (Bussie (2011, p. 31), pseudolistening (Adler \& Rodman, 2011, p. 136), interruptive listening (Wolvin \& Coakley, 1996, p. 389), and cataphatic listening that assigns what others say into categories imposed by the listener, often based on pre-conceptions or stereotypes (Waks, 2010, p. 2749).

In a literature review in the International Journal of Listening, Glenn (1989) identified 50 different definitions of listening. More recently, the International Listening Association (ILA) developed a definition of listening as "the process of receiving, constructing meaning from, and responding to spoken and/or non-verbal messages" (ILA, 1995, p. 4). In adopting this concise definition, the ILA reported considerable debate over whether "paying attention to incoming signals" and "remembering" should be added to the definition, and agreed that an expanded definition that might describe "effective listening" should be developed. From this and other relevant literature, the key elements of effective ethical listening can be identified as:

- Giving recognition to others as people or groups with legitimate rights to speak and be treated with respect (Bickford, 1996; Honneth, 2007; Husband, 2009); 
- Acknowledgement of others' views and expressions of voice, ideally in a timely way, the importance of which has been demonstrated in the Deliberatorium online consultation experiment conducted by MIT (Klein, 2007) and by the Obama presidential election campaigns (Macnamara, 2014);

- $\quad$ Paying attention to others (Bickford, 1996; Honneth, 2007; Husband, 2009, p. 441);

- Interpreting and constructing meaning from what others say as fairly and receptively as possible (Husband, 1996, 2000; ILA, 1995, p. 4);

- $\quad$ Trying as far as possible to achieve understanding of others' views, perspectives, and feelings (Bodie \& Crick, 2014; Habermas, 1984, 1987; Husband, 1996, 2000);

- $\quad$ Giving consideration to what others say such as in requests or proposals (Honneth, 2007; Husband, 2009); and

- Responding in an appropriate way after consideration has been given (Lundsteen, 1979; Purdy \& Borisoff, 1997). Scholars agree that 'appropriate' does not necessarily mean agreement or acceptance of what is said or requested, but research shows that an explanation or some statement is required in cases of non-compliance with requests and particularly in cases of wrongdoing or failure (Commission for Healthcare Audit and Inspection, 2007, p. 4).

These definitions are also informed and supported by human communication theories already noted, such as Gadamer's (1989) concept of openness and the dialogism and dialogue espoused by Bakhtin $(1981,1984)$ and Buber $(1958,2002)$, as well as theories of receptivity (Kompridis, 2011); reciprocity (Gouldner, 1960); hospitality (Silverstone, 2007); and interactivity (Pelias \& VanOosting, 1987). Also, literature on the ethics of listening (Beard, 2009; Bodie, 2010; Bodie \& Crick, 2014; Conquergood, 1985; Gehrke, 2009) is directly applicable to this analysis and informs theory building and practice in public relations.

\section{The importance of organizational listening}

Bimber, Flanagin and Stohl (2012) identify the central role of organizations in contemporary societies and usefully explore how individuals today engage with organizations using an increasing array of media and communication technologies. Particularly in industrialized and post-industrial societies with institutionalized politics and social systems - what Couldry (2010, p. 100) calls "complex societies" - citizens need to interact with an array of organizations on a regular basis in accessing goods and services, complying with laws and regulations, and living as agentic social actors. These include government departments and agencies, corporations, numerous NGOs, institutions such as police, hospitals, libraries, schools, universities, museums, associations, clubs, foundations, councils, and so on, as well as local businesses. This brings us then to consider how such organizations listen to their stakeholders and publics, noting that listening is the vital corollary of speaking and a requirement to achieve two-way communication, dialogue, and relationships.

\section{Listening in public relations literature}

Within public relations literature and related corporate and strategic communication literature that make explicit claims for two-way communication, dialogue, engagement, and relationships, it is particularly troubling that organizational listening is little studied or discussed. A search of articles published in Public Relations Review and Journal of Public Relations Research, identified as the two journals "most representative" of public relations scholarship globally by Kim, Choi, Reber, and Kim (2014, p. 116), found a distinct lack of research and critical analysis of listening.

A keyword search of Public Relations Review articles published between 1976 and 2014 found only 217 that mention listening anywhere in their text. However, only two articles focus 
specifically on listening - an analysis of President Nixon's 'Listening Posts' that began in 1969 but were quietly closed down in 1971 after being deemed a failure (Lee, 2012), and an analysis of audience research by arts institutions (Foreman-Wernet \& Dervin, 2006). Listening is mostly referred to in passing with no examination of what listening entails at an organization-public level. For instance, in an article titled 'Revisiting the concept of dialogue in public relations', Theunissen and Noordin (2012, p.10) cite Heath who suggests that "listening and speaking” are key elements of dialogue, but provide no further discussion of listening. In an analysis of Twitter use by US presidential candidates, Adams and McCorkindale say that "retweeting, when done appropriately, can show that candidates are listening to their constituents" (2013, p. 359). While retweeting involves some level of attention, recognition and response, resending 140-character tweets does not in any way meet the definitions of listening advanced in the literature cited. On the few occasions that methods of listening are discussed in public relations literature, listening is mostly equated with monitoring and environmental scanning (e.g., Sonnenfeld, 1982, p. 6).

A search of Journal of Public Relations Research identified 132 articles that mention the word 'listening' but, despite considerable discussion of dialogue, even fewer articles in this journal pay attention to listening and none examine how organizational listening is operationalized in organization-public relationships.

Listening also receives little attention in public relations research books and textbooks. For instance, 'listening' is not listed in the index of the main 'Excellence' text (Grunig et al., 2002) or in the index or contents of a dozen other international public relations and corporate communication texts examined (e.g., Botan \& Hazleton, 2006; Cornelissen, 2011; Tench \& Yeomans, 2009; Wilcox \& Cameron, 2010). Listening is mentioned once in the edited volume The Future of Excellence in Public Relations Communication Management (Toth, 2007), but this is in a chapter focused on interpersonal communication. Heath and Coombs (2006) provide the only definition of public relations that makes explicit mention of listening, describing public relations as:

The management function that entails planning, research, publicity, promotion, and collaborative decision making to help any organisation's ability to listen to, appreciate, and respond appropriately to those persons and groups whose mutually beneficial relationships the organisation needs to foster as it strives to achieve its mission and vision. (p. 7)

On the few occasions that listening is discussed in public relations literature, it is with an organization-centric focus. For example, the widely-used textbook Cutlip \& Center's Effective Public Relations commendably states that "effective public relations starts with listening, which requires openness and systematic effort” (Broom \& Sha, 2013, p. 243). However the text goes on to cite Schramm saying "feedback tells the listener how his message is being received" (Schramm, 1971, p. 26), suggesting a narrow approach to listening focused on transmitting the organization's messages and achieving organizational goals. In Today's Public Relations: An Introduction, Heath and Coombs (2006) say "today's public relations practitioner gives voice to organizations" and add that "this process requires the ability to listen". However, they similarly go on to narrowly configure listening by saying "listening gives a foundation for knowing what to say and thinking strategically of the best ways to frame and present appealing messages” (p. 346).

The only detailed discussion of listening in public relations literature thus far appeared in the 'Melbourne Mandate', a paper developed in 2012 by the Global Alliance for Public Relations and Communication Management (Global Alliance, 2014) and expanded in a subsequent article by 
Gregory (2015). This identifies “building a culture of listening and engagement” as one of three roles of public relations professionals and lists eight requirements to build a culture of listening in an organization (Gregory, 2015, p. 598).

It seems incongruous that in the sizeable body of literature on public relations and corporate communication that discusses two-way communication, dialogue, relationships, and symmetry between organizations and publics at length, there is scant research and little by way of descriptions or models of organizational listening. To address this gap and wider concerns about organizational listening in politics, management, business, and society generally, The Organizational Listening Project was commenced in 2013 and has collected extensive data on organization-public communication practices including public relations as reported and analyzed in the following.

\section{Methodology}

The aim of The Organizational Listening Project is to examine the practices, resources, effort and time committed by organizations to speaking to disseminate their messages and compare that with the practices, resources, effort and time committed by the same organizations to listening to their stakeholders and publics. Second, the project seeks to identify internal and external factors that influence the balance of speaking and listening, as well as tools, systems, technologies, resources, and practices that can facilitate dialogue and engagement.

\section{Research questions}

The overarching research question explored in this research was 'how, and how well, do organizations listen to their stakeholders and publics', based on the literature that shows listening is a fundamental corollary of speaking to achieve two-way communication, dialogue, engagement, and create and maintain relationships. In operationalizing the study, a number of specific research questions were investigated including:

RQ1: To what extent is organization-public communication two-way transactional and dialogic? RQ2: What are the main media and methods used by organizations for speaking (i.e., to express and disseminate the organization's voice) and the scale, frequency, and intensity of their use?

RQ3: What are the main media and methods used by organizations for listening to their publics and the scale, frequency, and intensity of their use?

RQ4: What barriers, obstacles, and challenges inhibit two-way communication including listening between organizations and their publics?

RQ5: Conversely, what tools, technologies, systems, methods, and other factors best facilitate scalable two-way communication including listening between organizations and their publics?

\section{Approach}

The most appropriate way to study organizational listening is by examining case studies of organizations at work going about their typical public interactions. Therefore, a naturalistic approach was taken in this study. Also, while a large amount of empirical data was collected, the research was interpretative as it required analysis of claims, observed behaviors, activities such as research and consultations, and documents such as plans and reports, and it was qualitative as the purpose was to explore how, and how well, organizations listen. This was not simply a study of how many inquiries organizations respond to or how many consultations they conduct, but how 
they listen in terms of giving recognition, acknowledgement, attention, interpretation, consideration, understanding, and response to others as defined in the literature. Hence, the study was conducted using qualitative case study methodology (Stake, 2008; Yin, 2009) within a naturalistic interpretive approach.

While an inductive approach to exploring issues, phenomena, and practices, and applying interpretative analysis to a relatively small number of cases to generate conclusions and theory lack the statistical generalizability of 'scientific' quantitative research methods, qualitative research can and should have credibility, dependability, confirmability, and some level of transferability, which contribute to the overall trustworthiness of the research, as noted by Lincoln and Guba (1985), Shenton (2004), and others. These were established through careful design of the research, transparency in relation to how the research was done (e.g., the sample and how it was selected), and rigorous conduct of the research such as recording interviews and observations and doing systematic analysis of transcripts.

\section{Sample}

The study was particularly interested in how large organizations with thousands or hundreds of thousands of stakeholders and multiple publics listen (i.e., large-scale listening rather than interpersonal, dyadic or small group listening). Also, the study was conducted with the intention of identifying common practices in different types of organizations in a range of industries and sectors and in a number of geographic regions to ensure the maximum relevance and transferability of findings. Therefore, a purposive sampling method was used in which selection of units or cases is "based on a specific purpose rather than randomly" (Tashakkori \& Teddlie, 2003, p. 713). As Miles and Huberman (1994) note, defined case (purposive) sampling for qualitative studies is informed by the conceptual question, not a concern for "representativeness" (p. 29). Bryman (1988) and others note that well-selected defined cases produce findings that have a broad generalizability to particular contexts, or what Lincoln and Guba (1985) and Shenton (2004) prefer to call transferability.

The sampling frame employed Miles and Huberman's three-stage approach for qualitative research sampling by selecting (1) some "exceptional" or exemplary cases; (2) some "discrepant", “negative” or "disconfirming” examples; and (3) some apparently typical examples (1994, p. 34). In simple terms, this can be described as selecting some cases at each end of the spectrum and some in the middle. Exceptional and exemplary examples were identified from academic articles, media reports, and announcements of specific initiatives in organizational listening, such as the MasterCard's Conversation Suite (MasterCard, 2014; Weiner, 2012). Discrepant negative examples were identified from media and public criticisms of organizations for lack of listening and engagement with stakeholders and citizens, such as criticism of the UK Government and its Department of Health in relation to complaints that led to the Mid Staffordshire hospitals crisis (Stationery Office, 2013) and reports of customer complaints about energy, finance, telecommunications, and other companies (e.g., FTC, 2015). Typical examples were chosen at random from large well-known organizations. This sampling approach also reflected purposive sampling strategies summarized by Teddlie and Yu (2007) based on the methodological advice of Glaser and Strauss (1967), Patton (2002) and others, including typical case sampling, extreme or deviant case sampling (also known as outlier sampling), maximum variation sampling, revelatory case sampling, and critical case sampling. The sample of cases studied was comprised of: 
1. A mix of government $(n=18)$, corporate $(n=14)$, and NGO and non-profit organizations ( $=4$ ) at national, state/regional, and local levels;

2. Organizations in each of the above categories in three countries - the UK $(n=18)$, the USA $(\mathrm{n}=11)$, and Australia $(\mathrm{n}=7)$;

3. Organizations with a substantial number of stakeholders and publics (i.e., primarily large organizations);

4. Organizations that are leaders or 'top three' in their sector, as these are likely to be representative of practices in the sector.

Thus, The Organizational Listening Project involved 36 case studies that were examined in depth over a two-year period, as outlined under 'Research methods'. To aid recruitment of the sample and frankness in discussions, de-identification of all participating organizations and individuals was provided.

\section{Research methods}

Noting that self-reporting by organization staff had the potential to overstate listening and that some organizations were likely to be reluctant to make admissions that indicated a lack of listening, the project used a triangulation approach to draw data from three sources.

1. In-depth interviews - A primary research method deployed was in-depth semi-structured interviews with senior staff in communication-related roles including chief communication officers (CCOs) and directors, heads, vice presidents, and general managers of communication and public relations. Interviews were also conducted with senior staff in specialist functions such as customer relations/customer relationship management (CRM), research (often referred to as insights), community relations, public consultation, social media monitoring and analysis, and internal/employee communication. Up to seven interviews were conducted in some organizations, while in others the head of communication preferred to provide all comment, soliciting information from colleagues as required. Furthermore, during the study it became apparent that some organizations outsource organization-public communication that potentially or explicitly involves listening, such as social media analysis, to specialist research firms and agencies. On the recommendation of the organizations studied, a number of these specialist research firms were added to the sample as they have first-hand knowledge of these practices. A total of 104 interviews were conducted during 2014-2015, an average of almost three interviews per organization. All interviews were conducted face-to-face by the author and ranged from 1.25 hours hour to three hours.

2. Document analysis - To help validate data gained in interviews, the study also collected a range of documents that contained evidence of organization-public communication activities. These included public relations and 'strategic communication' plans, reports of communication programs and activities, records of public consultations, and evaluation reports. In addition, a range of documents relating to public communication, consultation, and engagement were downloaded from corporate and government Web sites. More than 400 relevant documents were obtained and analyzed for evidence of organizational listening. All document analysis was conducted by the author using key word searches for terms such as 'listen', 'listening', and a range of synonyms and related concepts such as 'feedback', 'audience research', and 'audience insights'. 
3. Field tests (experiments) - Thirdly, field tests were conducted as mini-experiments in which the author and research associates submitted 'real life' inquiries, questions, complaints, and comments warranting a response via e-mail or to the Web sites and social media sites of organizations studied. During the period of research 25 such communications were submitted to organizations and responses were monitored and recorded.

\section{Data capture and analysis}

All formal interviews were digitally recorded and transcribed verbatim. Transcripts of interviews were analyzed inductively in the first stage of data processing using NVivo 10 to identify key issues, topics, and concepts discussed by participants in line with qualitative textual and content analysis procedures (Neuman, 2006; Punch, 1998; Shoemaker \& Reese, 1996). Almost 1,000 pages of transcripts were analyzed in NVivo to produce lists and 'word clouds' showing the most frequently occurring terms, concepts and phrases. After initial open coding focused on identifying key terms and topics in the texts, NVivo was used to undertake some second-level axial and pattern coding to group terms and concepts into categories (Glaser, 1978; Glaser \& Strauss 1967; Punch 1998, pp. 205, 210-221). These were derived from a mixture of inductive and deductive analysis. For instance, terms were categorized as 'listening-oriented' and 'speaking-oriented' where possible based on grouping synonyms and derivative words in the texts (inductive), while a priori categories were used to deductively categorize terms into specific fields of practice such as research, social media, customer relations, public consultation, and so on.

While bringing a systematic approach to data analysis, this somewhat mechanistic analysis told only part of the story, however. An important part of interpretative analysis was comparing transcripts of interviewees' statements with key documents accessed. For instance, if an interviewee claimed public consultation was undertaken, a report of the consultation was requested and examined to confirm or disconfirm claims made. Concurrently, results of field tests were tabulated to identify the rate and types of responses received.

\section{Findings - the 'crisis of listening'}

The communication media and channels most used by the organizations overall and for distributing their messages (RQ 2) were reported to be traditional media (press, radio, and TV publicity), followed by social media, and owned media such as Web sites and digital publications produced for corporate, government, and marketing communication purposes. These were reported to be used extensively by all organizations studied, mostly on a daily basis.

Functions such as social media communication where this function is managed by public relations, community relations, investor relations, and employee communication could be expected to be sites of considerable listening, given the explicit focus on two-way communication, engagement, dialogue, and relationships in public relations theory, as outlined in the literature. However, while The Organizational Listening Project did find some effective ethical listening by organizations undertaken through audience and social research, customer relations, public consultation, and some specialist social media initiatives in response to RQ 3, public relations and corporate communication demonstrated the least listening of the public communication practices studied ${ }^{2}$. Furthermore, the organizational listening that does occur was mostly instrumental, undertaken to serve the organization's interests such as gaining insights into consumer psychology to sell more products and services. 


\section{Rhetoric vs. reality}

Table 1 shows that, based on the volume of what interviewees talked about identified from NVivo analysis of interview transcripts, the organizations studied engaged in a near even balance of listening and speaking. In fact, this comparison suggests that they do slightly more listening through engagement, consultation, collaboration, and other ways than speaking in various forms such as producing content, distributing messages, and advocacy. The word cloud derived from NVivo analysis of interview transcripts shown in Figure 1 further confirms that practitioners talked the talk about 'engagement', being 'social', 'listening', and 'consultation', as well as 'media', 'talk', and 'likes'.

Table 1. A comparison of listening orientated and speaking orientated terms used by interviewees.

\begin{tabular}{lrlr}
\hline Listening-orientated terms & Mentions & Speaking-orientated terms & Mentions \\
\hline Engagement & 365 & Informed & 398 \\
\hline Listening & 312 & Talk & 291 \\
\hline Consultation & 230 & Content & 87 \\
\hline Audience & 64 & Message & 73 \\
\hline Interactive & 40 & Speak & 64 \\
\hline Hear & 35 & Broadcast & 47 \\
\hline Collaboration & 29 & Voice & 28 \\
\hline & & Advocacy & 17 \\
\hline & & Distribution & 10 \\
\hline & Disseminate & 2 \\
\hline TOTALS & $\mathbf{1 , 0 7 5}$ & & $\mathbf{1 , 0 1 7}$ \\
\hline \% & $\mathbf{5 1 \%}$ & & $\mathbf{4 9 \%}$ \\
\hline
\end{tabular}

Figure 1. The main communication-related terms discussed by interviewees.

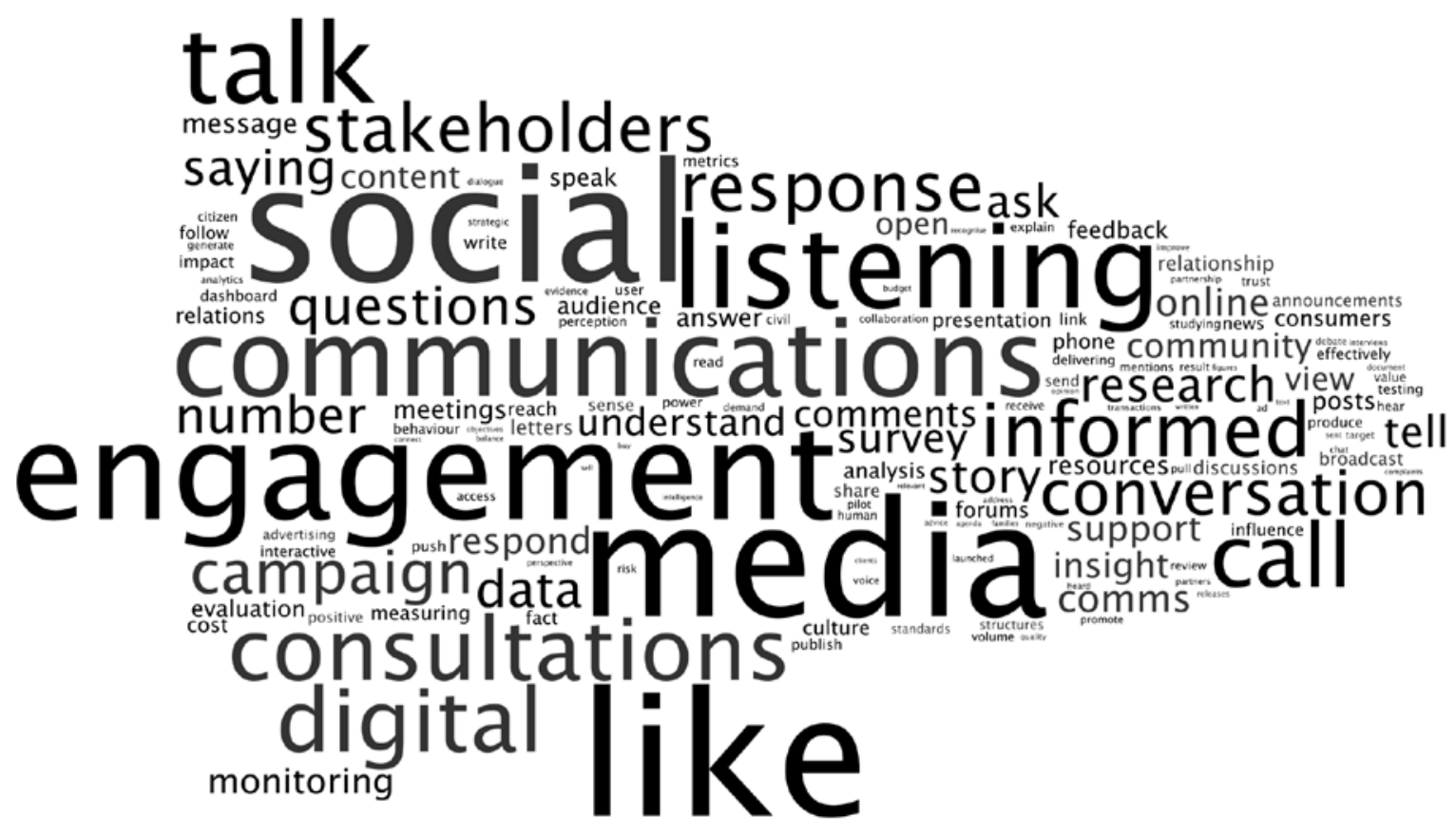


However, closer analysis presents a different picture. Despite frequent claims of listening, even the most upbeat listening claimants were often unable to provide examples and were circumspect in giving an overall rating to their organization's listening. The final question posed to all interviewees asked them to make an overall estimate, in approximate terms, of the proportion of their budget, time, and resources that were spent on speaking-related activities and the proportion of their budget, time, and resources that were spent on listening-related activities. The highest claims for listening were made by practitioners involved in customer relations and public consultation, who rated their work as primarily listening, suggesting ratios of 60:40 and 70:30 listening versus speaking respectively. However, beyond these specialized public communication fields, the majority of interviewees were reflexive and self-critical. Overall, around one-third of interviewees characterized their public communication activities as between 80:20 and 90:10 speaking versus listening. One rated his organization's speaking to listening ratio as 95:5. Even among those who claimed high levels of listening in functions such as research or public consultation, most acknowledged that these listening-oriented activities occur only occasionally sometimes only once a year or even once every few years. While these are not statistically reliable quantitative ratings, averaging responses from interviewees indicates that, overall, the public communication of most organizations is around 80:20 speaking versus listening. Given that these are self-assessments, claims in relation to time and resources spent on listening are more likely to be generous rather than minimalist and present a disturbing picture in relation to RQ 1 .

Figure 2. The main terms and concepts discussed by interviewees.

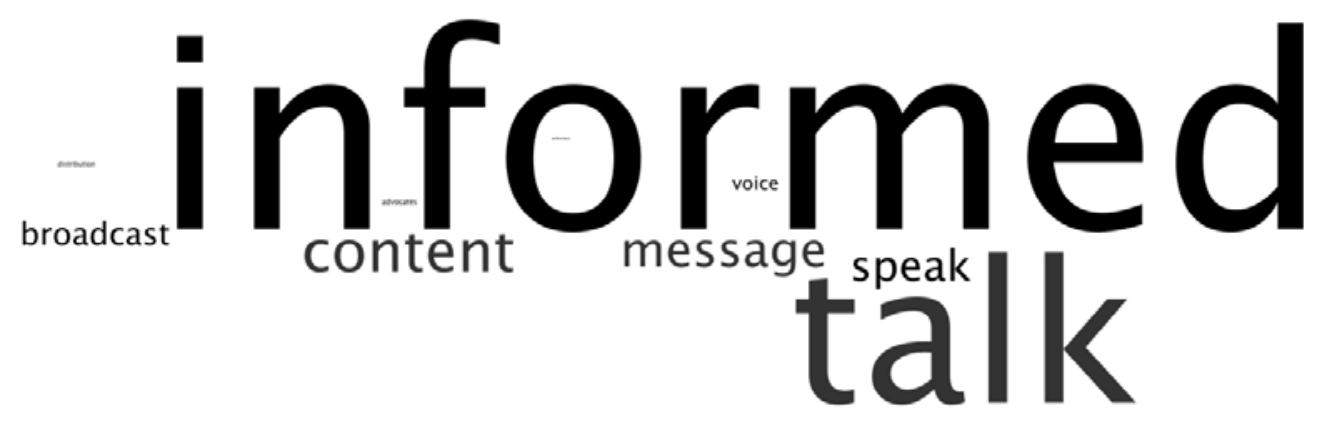

\section{The effect of organizational culture and top-down management}

Close examination of public relations and related strategic communication functions in specific cases further identified a focus on speaking to distribute the organization's messages and a lack of listening. The headquarters public relations function of a global automotive manufacturer emphasized the determining role of culture and structure in shaping practice, a significant finding in relation to RQ 4. The public relations manager was frank saying: "The culture here is mostly a command and control one. The senior management mostly have engineering backgrounds. That means we are very process driven and very focused on numbers and data" (personal communication, January 30, 2015). This and other case studies examined indicates that orientation of public relations towards marketing and sales in some organizations is another barrier to open effective listening (RQ 4).

Even though dialogue allegedly "has become ubiquitous in public relations writing and scholarship” (Theunessin \& Noordin, 2012, p. 5), this interviewee rated the ratio of speaking to listening in his company as 90-95 per cent speaking compared with 5-10 per cent listening. He 
reported that the corporate public relations team in the company's headquarters was made up of 70 staff. In addition, its two major global brands each have their own public relations teams and the corporation operates through 18 national sales companies around the world which each have their own marketing staff. But he explained that the brand marketing teams and national sales companies are almost exclusively focused on marketing and promotion of products. He said the company conducted social media monitoring and analysis using We Are Social and also Ogilvy's Listening Post technology platform, but this was mostly involved tracking its volume of mentions and identifying criticisms to address and opportunities to exploit.

In terms of channels and media for listening (RQ 3), the auto manufacturer used research including surveys as well as focus groups, but this was mostly undertaken for testing new designs and features for its products. The public relations manager said "I would like to be measuring engagement" and added "we would like to use listening tools such as more sophisticated social media monitoring tools to track comments and public opinion on issues. But it is a trade off on how much we can spend" (personal communication, January 30, 2015). The company processes Web inquiries, letters and e-mails through its customer relations department and also does some public consultation on local issues, such as when it is building or expanding a plant. The public relations manager said "then we go beyond the legal requirements and talk to local schools, sponsor local sporting teams, and other engagement activities”. But it was somewhat surprising to find the headquarters public relations department of a major global automotive manufacturer with such limited influence, budget, and scope. The public relations manager has a vision of greater engagement, but it was clear that the culture of an organization and its structure define how public relations is conceived and practiced (RQ 3).

This is further borne out in examination of the public relations function in another industry in another country. A long-time public relations practitioner, who was general manager (GM) of corporate affairs at the time of this research with a national wholesaler that supplies a large network of franchised stores, provided a sad and sobering description of how some organizations do not listen. The GM corporate affairs said "the only communication we have with our key stakeholders, our retailers, is our annual general meeting, and the CEO insists on a quarterly update newsletter which I don't think anyone reads". The company uses social media, but in "a very fragmented and broadcast way", according to the GM (personal communication, March 6, 2015). He reported that social media are managed through three different units in the company - corporate affairs is responsible for the corporate Twitter and LinkedIn accounts; the marketing department uses a variety of social media for "online selling"; and a digital team has been created separately to operate the company's Facebook site. Furthermore, the digital team has been put under the control of the IT department. The GM, who is purportedly responsible for the company's overall public communication, said:

They don't have a clue about communication. They are focused on technology platforms and systems. We use Twitter and LinkedIn to put out announcements. There's a constant flow of little bits of information. We receive very little feedback or comment. (personal communication, March 6, 2015)

The company does do an annual staff survey conducted by an independent research firm. However, the GM corporate affairs said there is little face-to-face communication between management and staff. “They don’t go out and talk to people.” He was even blunter in relation to listening, adding: "And they certainly don't listen to them" (personal communication, March 6, 2015). 
So how does such a situation exist when an experienced communication professional is appointed to a senior management role in an organization? A further finding in relation to RQ 3 is that this occurs because lack of listening in the company extends to not listening to its own head of communication. The GM corporate affairs said:

Senior management doesn't listen to advice. They tell me that I need to develop a PR strategy to stop criticism. I tell them to stop doing what they are doing to cause the criticism, but they don't take any notice. I try to explain that they are asking me to put lipstick on a pig. In the end, it's still a pig. (personal communication, March 6, 2015)

This failure of senior management to take advice from communication professionals is an underrecognized factor in public relations and corporate communication literature, particularly in critical analyses of practices such as public relations. For example, in reports of so-called 'PR disasters' the blame is frequently attributed to the actions of, or lack of, public relations or corporate communication. But there is little analysis behind the scenes to identify what advice and recommendations were provided by public relations and corporate communication staff or consultants. Berger (2005) and, more recently, Gregory and Willis (2013), and Tilley (2015) have noted that senior executives of organizations referred to as the 'dominant coalition' in public relations literature (Dozier, et al, 1995, p. 15) have the power to reject advice, and frequently do. In an analysis of public relations ethics, Tilley identified the role of hierarchies and several types of what she calls "power silos" including the power that clients have over consultancies and power siloes inside organizations that can make it difficult for communication practitioners to get recommendations in front of decision makers (2015, pp. 85-86). Berger explains that this can restrict practitioners' ability to positively influence organization decision making. Similarly Gregory and Willis stress that, no matter how good the relationship between a public relations practitioner and their employer or client, whether senior management takes advice or not is a choice. This study found that at least in some so-called communication breakdowns, organization management had failed to take the advice of professional public communication staff.

\section{Focus on information transmission and mass media}

However, the cases analyzed also indicate that the thinking, language, and practices of public relations practitioners are largely oriented to distributing information with the intention of informing, educating, and persuading (i.e., speaking for organizations), rather than listening. Practitioners spoke frequently of “content”, “messages” (the organization's), and "storytelling” (the organization's). An overwhelming focus is on what the executive director of the UK Government Communication Service, Alex Aiken, calls "SOS - sending out stuff” (personal communication, September 29, 2014).

This is epitomized in the reported experience of the vice president (VP), corporate communication in a leading US broadband and telecommunications company, who is working to introduce reform. In the months immediately preceding this study the VP responsible for corporate public relations gained the support of management to "ban press releases" 3 other than formal public announcements that the company is legally required to issue. The VP, corporate communication stated:

We're not allowed to do press releases here - other than announcements required by the stock exchange. You must think first about the audience and then the story, and then determine what is the best vehicle? That vehicle or channel is rarely press releases. (personal communication, January 16, 2010) 
He explained that writing and distributing what this analysis calls media releases "was so habitual ... there's no thought that goes into it. There's no thought about the audience, there's no thought about the behavior change that you're trying to drive”. The company's decision to stop issuing media releases becomes understandable upon hearing his rationale.

I think at last count, we issued between 2,000 and 3,000 press releases a year. There's no way for that volume of activity to not cost a lot of money - all for something that you cannot prove the value of except that I can show the CEO the coverage that those $\mathrm{X}$ thousand press releases generated and hopefully he won't ask me to verify it in terms of impact. (personal communication, January 16, 2015)

This concern was echoed by a major UK government department that has abolished what the director of communication calls "the disposable announcement", which he described as announcements that are drafted, often many times, on numerous minor matters based on habit and a predilection for distributing all information through media. Reflecting on the practice he said:

We crafted an announcement and then moved on to the next announcement and the next announcement ... the idea of getting away from the disposable announcement is recognizing that we're not getting the maximum opportunity or value out of what we put out. (personal communication, September 29, 2014)

Such actions to substantially reduce or even eliminate media releases - a long-standing and staple public relations activity since Ivy Lee pioneered the practice in the early 1900s (Hiebert, 1966) reflect a minority view in PR practice, however. Most public relations practitioners interviewed listed 'media publicity' as their primary activity (RQ 2). This function is by nature transmissional and enacts speaking rather than listening, particularly when combined with a lack of research for either planning or evaluation which was a characteristic of almost all organizations' public relations functions studied.

The VP of corporate communication for the US broadband and telecommunications company said “there's this dirty little secret that I talk to my team about”. He explained this 'dirty little secret' as follows:

We have, for good or bad, convinced our clients, our business partners, if you will, that what we do media clips, coverage, volume - matters. It's a dirty little secret because what we all really know is that we can't really prove that it has any meaningful impact on the business ... I think we have two choices. You can continue to close your eyes and hope that people continue to believe that clips media coverage - mean something valuable to the business. But we know today it doesn't. We could shake a stick and get a ton of coverage today and still turn around tomorrow and have our lunch handed to us by our competitors. Or we can use data-informed insights to engage in a way that actually has meaningful impact on brand affinity, perceptions, and the way people think about us as an organization. (personal communication, January 16, 2015)

\section{Social media use is not social}

Along with research, customer relations contact, and public consultation, social media are primary channels that potentially afford listening (RQ 2). However, the senior vice president and vice president of the digital and social media team in the New York office of one of the world's leading public relations firms were blunt in discussing the use of social media and research in public relations, saying: 
The majority of what we do for clients is monitoring their own stuff - 90 per cent of our clients use us for media relations. It's very media-centric. One major client issued 26 press releases in four days during a show. They considered it a success based on the volume of publicity ... a lot of PR is still measured in terms of press clippings. And measurement is still mostly historical - looking back at what was done. (personal communication, January 22, 2015)

Their comments reveal strong organization-centricity and self-interest. They added: "We are monitoring and analyzing social media, but it's mostly output monitoring - that is, monitoring what the organization posts to see how much exposure it receives such as views, likes, shares, and so on". They also reported that they "track issues”, but they described this in terms of identifying issues that clients could "jump on" for promotional gain. They referred to social media monitoring in this context as facilitating "news jacking” and "meme jacking” and gave an example.

For instance, if there is a story of someone famous or important taking a 'selfie' and we have a cell phone client, they can jump online and say 'hey, our cell phone can take wide angle pics' or whatever to position their products. (personal communication, January 22, 2015)

Despite the interview taking place in the New York headquarters of the public relations firm, the digital and social media team advised that they used only basic tools for social media monitoring including Google News and Factiva as well as some basic social media analysis tools such as Hootsuite, although they did note that some clients used Brandwatch and services such as Cision. The SVP and VP acknowledged that "a lot of digital marketing is e-mail spam". They added somewhat more optimistically: "We are seeing more sophisticated uses of social media and more transactional uses. But that's a minority of organizations”. This confirms findings of research by Kent who says that, even in current best practice, "public relations professionals use social media as marketing and advertising tools” (2013, p. 340).

\section{One-way 'communication' dominates}

While PR practitioners showed evidence of being very (even frenetically) responsive to journalists as part of media relations, several corporate public relations departments did not reply to general requests for information and one international public relations agency failed to respond in any way to e-mails sent to their offices on three continents asking about their services, despite declaring elsewhere that "public engagement is the future of public relations" (Ovaitt, 2008).

Mark Collinson, a partner in a specialist investor relations consultancy in Los Angeles who agreed to be quoted, openly acknowledges that there is a lack of listening even in specialized fields of public relations such as investor relations, issue management, and crisis communication saying that in the past 10 years of practice he had "never heard a company say, for example, 'here are some questions we have for you, our investors"”. He added in relation to issue management and crisis communication: "My experience is that few companies want to know what anybody thinks about a mistake, they want to tell people what they should think about the mistake" (personal communication, May 28, 2015).

While going under the title 'communication', 'communications', or 'comms' for short, rather than public relations, a number of US and UK government departments and agencies also exhibited a focus on one-way transmission of information (i.e., speaking) with little attention to listening. Terms that frequented descriptions, written reports, and evaluations of their activities included "informing”, “disseminating”, “educating”, "showing”, “telling”, “distributing”, and "broadcasting”. 


\section{PR creates an 'architecture of speaking'}

Even though communication literature and some public relations texts call for listening through methods such as hotlines and ombuds (Broom \& Sha, 2013, p. 205), social media (Kent, 2013; Macnamara, 2014), and research and other means (Gregory, 2015), this study found that, in both the public and private sector, the function of public relations is principally involved in creating an architecture of speaking for organizations comprised of structures, systems, resources, tools, and technologies such as Web sites, databases, mailing lists, events, presentations, videos, media campaigns, speeches, reports, newsletters, brochures, and so on. Many organizations spend sevenfigure sums ostensibly on communication, but in reality these are predominantly spent on organizational speaking, with comparatively little attention to systems, tools, technologies, or resources for listening. Within public relations this study found little information in relation to RQ 5 , although investigation of other organizational functions such as specialized public consultation afforded some insights to inform future practice as reported elsewhere (AUTHOR, 2016).

\section{Discussion - the work and 'architecture of listening' in organizations}

Bickford (1996) pointed out that listening involves work. As well as doing the work of speaking on behalf of organizations such as writing speeches and media releases, producing Web sites and content such as videos, and arranging events dominated by organization presentations, communication practitioners need to do the work of listening. This can include open-ended research, public consultation, broad-based social media monitoring (not just tracking the organization's coverage), and collecting and analyzing feedback, comments, and complaints.

In addition, listening at the organizational level, which typically involves large-scale listening, requires what can be described as an architecture of listening. This recognizes that large-scale listening requires tools and technologies, as it cannot be undertaken aurally or even face-to-face in many cases. However, while technologies can provide tools to aid listening, such as media and internet monitoring and text analysis software, the concept of an architecture of listening is not an argument for technological determinism. Findings in this project suggest that effective ethical organizational listening requires a number of elements, features, and characteristics. These include:

1. An organizational culture that is open to listening as defined by Honneth (2007), Husband (1996, 2009) and, most recently, Gregory (2015) - that is, one that recognizes others' right to speak, pays attention to them, tries to understand their views and responds with at least acknowledgement, although not necessarily agreement. This is similar to Coleman's identification of "ideology" as a barrier to organizational listening (2013, p. 3);

2. Policies that specify and require listening, including processes to address issues of power differentials and the 'politics of listening' as discussed by Dreher (2009);

3. Systems that are open and interactive, such as Web sites that allow visitors to post comments and questions, vote, and so on;

4. Technologies to aid listening, such as monitoring tools or services for tracking media and online comment; automated acknowledgement systems; text analysis software for sensemaking, and even specialist argumentation software to facilitate meaningful consultation and debate; 
5. Resources including staff assigned to operate listening systems and do the work of listening, such as establishing spaces (e.g., forums and consultations), inviting comment, and monitoring, analyzing, and responding to comments and questions;

6. Skills for listening; and

7. Articulation of what the organization 'hears' to policy-making and decision-making. While dialogic and ethical listening do not imply or require that every comment and suggestion should be agreed to and acted on, unless there is a link to policy-making and decision-making for consideration of what is said to an organization, voice has no value - or, in Couldry's terms, it does not matter.

\section{Conclusions}

Contemporary public relations theory identifies, at least in a normative sense, that listening is fundamental to ethical public communication. As Coombs and Holladay have said in relation to ethics in public relations:

There is no magical code of conduct that will solve all ethical concerns experienced by public relations professionals ... The best advice is that public relations practitioners must listen and utilize two-way communication to be ethical. Two-way communication sets the stage for mutual influence. You cannot be influenced by a group if you never hear it. (2007, p. 48)

Fawkes (2015) maps a future approach for public relations that challenges both the dominant paradigm and critical theorists. She argues that public relations theorists need to deconstruct claims that public relations serves society, which are found in Excellence theory and many public relations codes of ethics, and look "beyond the insistence that ethics resides in symmetry, recognizing the essentially asymmetric, fluid and contradictory nature of most human relationships". She says that public relations also needs to move past the critical perspective to "consider how to engage with, rather than simply reject, those holding other views” (p. 208). Referring to a study by Pieczka (2011), Fawkes notes that "those who genuinely practiced listening and exchanging shifted their position to incorporate aspects of the other rather than 'manage' them" (2015, p. 205).

Even proponents of advocacy approaches to public relations and would-be persuaders need to listen. Only propagandists focus on one-way disseminating of their messages. Through lack of attention to listening, public relations is fundamentally failing to operationalize excellent, dialogic, relationships oriented, and sociocultural theories and models, and also failing to practice an ethical approach to rhetoric and a participatory, networked, or emergent approach to strategic communication as it claims to do.

However, organizational listening is easier said than done because of the challenges of scale and diversity of views among stakeholders and publics that can lead to cacophony rather than consensus. This study has identified multiple elements that need to be designed in to an organization to facilitate effective ethical organizational listening. The work of listening and the need for an architecture of listening provide important contributions to public relations theory and can help address a significant theory-practice gap. 
As well as being necessary from an ethical perspective, there is evidence that there are significant benefits available to organizations from effective ethical listening. For example, a study of 20 companies by Yang, Kang and Cha found "a significant positive association existed between the perceived quality of dialogic communication and the level of trust” (Yang, Kang, \& Cha, 2015, p. 187). The study further reported that openness to stakeholders and publics is "especially germane in engendering public trust” (p. 189). Elsewhere, a number of academic, business, and professional studies have reported that listening leading to true dialogue and engagement can result in increased employee retention and productivity, increased customer loyalty, improved customer service, reduced industrial disputation, and reduced crises and conflicts affecting organizations (Benner \& Tushman, 2003; Bentley, 2010; Kluger, 2012; Leite, 2015). Thus, organizational listening is an important subject for further research and greater attention in practice.

\section{References}

Aarts, N. (2009). Een gesprek zonder einde [A never ending conversation]. Amsterdam, The Netherlands: Vosspuspers.

Aarts, N., \& Van Woerkum, C. (2008). Strategische communicatie [Strategic communication]. Assen, The Netherlands: Van Gorcum.

Adams, A., \& McCorkindale, T. (2013). Dialogue and transparency: A content analysis of how the 2012 presidential candidates used Twitter. Public Relations Review, 39(4), 357-359.

Adler, R., \& Rodman, G. (2011). Understanding communication (11th ed.). New York, NY: Oxford University Press.

Argenti, P., \& Forman, J. (2002). The power of corporate communication: Crafting the voice and image of your business. New York, NY: McGraw-Hill.

Bakhtin, M. (1981). The dialogic imagination: Four essays. Austin, TX: University of Texas Press.

Bakhtin, M. (1984). Problems of Dostoevsky's poetics (C. Emerson, Ed. \& Trans.). Minneapolis, MN: University of Minnesota Press. (Original work published 1963)

Baxter, L. (2011). Voicing relationships: A dialogic perspective. Thousand Oaks, CA: Sage.

Beard, D. (2009). A broader understanding of the ethics of listening: Philosophy, cultural studies, media studies, and the ethical listening subject. International Journal of Listening, 23(1), 7-20.

Benner, M., \& Tushman, M. (2003). Exploitation, exploration, and process management: The productivity dilemma revisited. Academy of Management Review, 28, 238-256.

Bentley, S. (2010). Listening practices: Are we getting any better? In A. Wolvin (Ed.), Listening and human communication in the $21^{\text {st }}$ century (pp. 181-192). Malden, MA: Wiley-Blackwell.

Berger, B. (2005). Power over, power with, and power to relations: Critical reflections on public relations, the dominant coalition and activism. Journal of Public Relations Research, 17(1), 5-28.

Berger, B. (2007). Public relations and organizational power. In E. Toth (Ed.), The future of excellence in public relations and communication management: Challenges for the next generation (pp. 221-234). Mahwah, NJ: Lawrence Erlbaum.

Berlo, D. (1960). The process of communication: An introduction to theory and practice. New York: Harcourt/Holt, Rinehart \& Winston.

Bickford, S. (1996). The dissonance of democracy: Listening, conflict and citizenship. Ithaca, NY and London: Cornell University Press.

Bimber, B., Flanagin, A., \& Stohl, C. (2012). Collective action in organizations: Interaction and engagement in an era of technological change. New York, NY: Cambridge University Press.

Bodie, G. (2010). Treating listening ethically. International Journal of Listening, 24, 185-188.

Bodie, G., \& Crick, N. (2014). Listening, hearing sensing: Three modes of being and the phenomenology of Charles Sanders Peirce, Communication Theory, 24(2), 105-123.

Botan, C., \& Hazleton, V. (Eds.). (2006). Public relations theory II. Mahwah, NJ: Lawrence Erlbaum.

Bowen, S. (2008). A state of neglect: Public relations as 'corporate conscience' or ethics counsel. Journal of Public Relations Research, 20(3), 271-296. 
Broom, G. (1977). Co-orientational measurement in public issues. Public Relations Review, 3, 110-119.

Broom, G., \& Sha, B. (2013). Cutlip \& Center's effective public relations (11th ed.). Boston MA: Pearson.

Bryman, A. (1988). Quantity and quality in social research. London, UK: Unwin Hyman.

Buber, M. (1958). I and thou (R. Smith, Trans.). New York: Scribners. (Original work published 1923, 2nd ed. 1987)

Buber, M. (2002). Between man and man (R. Smith, Trans.). London, UK: Kegan Paul. (Original work published 1947)

Budd. J. (1995). Commentary: Communications doesn't define PR, it diminishes it. Public Relations Review, 21(3), 177-179.

Bussie, J. (2011). Reconciled diversity: Reflections on our calling to embrace our religious neighbours. Intersections, 33, 30-35.

Calder, G. (2011). Democracy and listening. In M. Crumplin (Ed.), Problems of democracy: Language and speaking (pp. 125-135). Oxford, UK: Inter-Disciplinary Press.

Cameron, G. (1997). The contingency theory of conflict management in public relations. Proceedings of the Norwegian Information Service, Oslo, Norway.

Carey, J. (2009). Communication as culture: Essays on media and culture. New York: Routledge. (Original work published 1989)

Center, A., \& Jackson, P. (1995). Public relations practices: Management case studies and problems ( ${ }^{\text {th }}$ ed.). Englewood Cliffs, NJ: Prentice Hall.

Coleman, S. (2013, February 1). The challenge of digital hearing. Journal of Digital and Media Literacy. Retrieved from http://www.jodml.org/2013/02/01/challenge-of-digital-hearing

Commission for Healthcare Audit and Inspection. (2007, October). Is anyone listening? A report on complaints handling by the NHS. London, UK: Author. Retrieved from http://www.bipsolutions.com/docstore/pdf/18646.pdf

Conquergood, D. (1985). Performing as a moral act: Ethical dimensions of the ethnography of performance. Literature in Performance, 5(2), 1-13.

Coombs, T., \& Holladay, S. (2007). It's not just PR: Public relations in society. Malden, MA: Blackwell.

Cornelissen, J. (2004). Corporate communications: Theory and practice. London, UK and Thousand Oaks, CA: Sage.

Cornelissen, J. (2011). Corporate communication: A guide to theory and practice (3rd ed.). London, UK and Thousand Oaks, CA: Sage.

Couldry, N. (2009). Commentary: Rethinking the politics of voice. Continuum: Journal of Media \& Cultural Studies, 23(4), 579-582.

Couldry, N. (2010). Why voice matters: Culture and politics after neoliberalism. London, UK and Thousand Oaks, CA: Sage.

Craig, R. (1999). Communication theory as a field. Communication Theory, 9, 119-161.

Craig, R. (2006). Communication as a practice. In G. Shepherd, G. St John, \& T. Striphas (Eds.), Communication as ... Perspectives on Theory (pp. 38-49). Thousand Oaks, CA: Sage.

Craig, R., \& Muller, H. (Eds.). (2007). Theorizing communication: Readings across traditions. Thousand Oaks, CA: Sage Publications.

Crawford, K. (2009). Following you: Disciplines of listening in social media. Continuum: Journal of Media \& Cultural Studies, 23(4), 525-535.

Curtin, P., \& Gaither, T. (2005). Privileging identity, difference and power: The circuit of culture as a basis for public relations theory. Journal of Public Relations Research, 17(2), 91-115.

Cutlip, S., \& Center, A. (1952). Effective public relations. Englewood Cliffs, NJ: Prentice-Hall.

Devin, B., \& Lane, A. (2014). Communicating engagement in corporate social responsibility: A metalevel construal of engagement. Journal of Public Relations Research, 26(5), 436-454.

Dewey, J. (1916). Democracy and education, New York, NY, Macmillan.

Dewey, J. (1927). The public and its problems. New York, NY: Henry Molt \& Co.

Dobson, A. (2014). Listening for democracy: Recognition, representation, reconciliation. Oxford, UK: Oxford University Press. 
Downing, J. (2007). Grassroots media: Establishing priorities for the years ahead. Global Media Journal (Australia Edition), 1(1), 1-16.

Dozier, D., Grunig, L., \& Grunig, J. (1995). Manager’s guide to excellence in public relations and communication management. Mahwah, NJ: Lawrence Erlbaum.

Dreher, T. (2008). Media, multiculturalism and the politics of listening. In E. Tilley (Ed.), Power and place: Refereed proceedings of the Australian and New Zealand Communication Association Conference 2008 (pp. 1-14). Massey University, Palmerston, New Zealand.

Dreher, T. (2009). Listening across difference: Media and multiculturalism beyond the politics of voice. Continuum: Journal of Media \& Cultural Studies, 23(4), 445-458.

Dryzek, J. (2000). Deliberative democracy and beyond: Liberals, critics, and contestations. Oxford, UK and New York, NY: Oxford University Press.

Edwards, L. (2012). Defining the 'object' of public relations research: A new starting point. Public Relations Inquiry, 1, 7-30.

Edwards, L., \& Hodges, C. (Eds.). (2011). Public relations, society and culture: Theoretical and empirical explorations. Abingdon, UK: Routledge.

Erickson, T. (2008). Plugged in: The generation Y guide to thriving at work. Boston, MA: Harvard Business School.

Falkheimer, J., \& Heide, M. (2011, May). Participatory strategic communication: From one- and two-way communication to participatory communication through social media. Paper presented at the International Communication Association 2011 pre-conference, 'Strategic communication - A concept at the center of applied communications', Boston, MA.

Fawkes, J. (2015). Public relations ethics and professionalism: The shadow of excellence. Abingdon, Oxon., UK: Routledge.

Ferguson, M. (1984, August). Building theory in public relations: Interorganisational relationships as public relations paradigm. Paper presented at the conference of the Association for Education in Journalism and Mass Communication. Gainesville, FL.

Fishkin, J. (1995). The voice of the people: Public opinion and democracy. New Haven, CT: Yale University Press.

Flynn, J., Valikoski, T., \& Grau, J. (2008). Listening in the business context: Reviewing the state of research. International Journal of Listening, 22(2), 141-151.

Foreman-Wernet, L., \& Dervin, B. (2006). Listening to learn: 'Inactive' publics of the arts as exemplar. Public Relations Review, 32, 287-294.

Foss, S., \& Griffin, C. (1995). Beyond persuasion: A proposal for an invitational rhetoric. Communication Monographs, 62, 2-18.

Freeman, R. (1984). Strategic management: A stakeholder approach. London, UK: Pitman.

FTC [Federal Trade Commission]. (2015). Identity theft tops FTC's consumer complaint categories again in 2014. Press Release, February 27. Retrieved from https://www.ftc.gov/news-events/pressreleases/2015/02/identity-theft-tops-ftcs-consumer-complaint-categories-again-2014

Gadamer, H. (1989). Truth and method (2nd ed., J. Weinsheimer \& D. Marshall, Trans.). New York, NY: Crossroad. (Original work published 1960)

Gehrke, P. (2009). Introduction to listening, ethics, and dialogue: Between the ear and eye: A synaesthetic introduction to listening ethics. International Journal of Listening, 23(1), 1-6.

Glaser, B. (1978). Theoretical sensitivity. Mill Valley, CA: Sociology Press.

Glaser, B., \& Strauss, A. (1967). The discovery of grounded theory: Strategies for qualitative research. Chicago, IL: Aldine.

Glenn, E. (1989). A content analysis of fifty definitions of listening. The International Journal of Listening, 3(1), 21-31.

Global Alliance. (2014). The Melbourne Mandate. Retrieved from http://www.globalalliancepr.org/website/page/melbourne-mandate

Green, J. (2010). The eyes of the people: Democracy in an age of spectatorship. New York, NY: Oxford University Press.

Gregory, A. (2015). Practitioner-leaders' representation of roles: The Melbourne Mandate. Public Relations Review, 41(5), 598-606. doi: 10.1016/j.pubrev.2014.02.030 
Gregory, A., \& Willis, P. (2013). Strategic public relations leadership. London, UK: Routledge.

Gouldner, A. (1960). The norm of reciprocity: A preliminary statement. American Sociological Review, 25(2), 161-178.

Grunig, J. (1997). A situational theory of publics: Conceptual history, recent challenges and new research. In D. Moss, T. MacManus, \& D. Verčič (Eds.), Public relations research: An international perspective (pp. 3-48). London, UK: International Thomson Business Press.

Grunig, J., Grunig, L., \& Dozier, D. (2006). The excellence theory. In C. Botan \& V. Hazleton (Eds.), Public relations theory II (pp. 21-62). Mahwah, NJ: Lawrence Erlbaum.

Grunig, J., \& Hunt, T. (1984). Managing public relations. Orlando, FL: Holt, Rinehart \& Winston.

Grunig, L., Grunig J., \& Dozier D. (2002). Excellent organisations and effective organisations: A study of communication management in three countries. Mahwah, NJ: Lawrence Erlbaum.

Habermas, J. (1984). Theory of communicative action volume 1: Reason and the rationalization of society (T. McCarthy, Trans.). Boston, MA: Beacon Press. (Original work published in German 1981)

Habermas, J. (1987). The theory of communicative action volume 2: Lifeworld and system: A critique of functionalist reason (T. McCarthy, Trans.). Boston, MA: Beacon Press. (Original published in German 1981)

Hallahan, K., Holtzhausen, D., van Ruler, B., Verčič, D., \& Sriramesh, K. (2007). Defining strategic communication, International Journal of Strategic Communication, 1(1), 3-35.

Heath, R. (2001). A rhetorical enactment rationale for public relations: The good organization communicating well. In R. Heath (Ed.), Handbook of public relations (pp. 31-50). Thousand Oaks, CA: Sage.

Heath, R. (2006). A rhetorical theory approach to issues. In C. Botan \& V. Hazleton (Eds.), Public relations theory II (pp. 63-99). Mahwah, NJ: Lawrence Erlbaum.

Heath, R. (2007). Management through advocacy: Reflection rather than domination. In E. Toth (Ed.) The future of excellence in public relations and communication management (pp. 41-65). Mahwah, NJ: Lawrence Erlbaum.

Heath, R. (2009). The rhetorical tradition: Wrangle in the marketplace. In R. Heath, E. Toth \& D. Waymer (Eds.), Rhetorical and critical approaches to public relations II (pp. 17-47).New York, NY: Routledge.

Heath, R., \& Coombs, T. (2006). Today's public relations: An introduction. Thousand Oaks, CA: Sage. Hiebert, R. (1966). Courtier to the crowd: The story of Ivy Lee. Ames, IA: Iowa State University Press.

Hon, L., \& Grunig, J. (1999). Guidelines for measuring relationships in public relations. Gainesville, FL: Institute for Public Relations. Retrieved from http://www.instituteforpr.org/measuring-relationships

Honneth, A. (2007). Disrespect. Cambridge, UK: Polity Press.

Husband, C. (1996). The right to be understood: Conceiving the multi-ethnic public sphere. Innovation: The European Journal of Social Sciences, 9(2), 205-215.

Husband, C. (2000). Media and the public sphere in multi-ethnic societies. In S. Cottle (Ed.), Ethnic minorities and the media (pp. 199-214). Buckingham, UK: Open University Press.

Husband, C. (2009). Commentary: Between listening and understanding. Continuum: Journal of Media \& Cultural Studies, 23(4), 441-443.

ILA (International Listening Association). (1995). An ILA definition of listening. Listening Post, 53, 1, 4-5. Retrieved from http://www.listen.org/ListeningPost

Johnston, K. (2014). Public relations and engagement: Theoretical imperatives of a multidimensional concept. Journal of Public Relations Research, 26(5), 381-383.

Kang, M. (2014). Understanding public engagement: Conceptualizing and measuring its influence on supportive behavioral intentions. Journal of Public Relations Research, 26(5), 390-416.

Kent, M. (2013). Using social media dialogically: Public relations role in reviving democracy. Public Relations Review, 39, 337-345.

Kent, M., \& Taylor, M. (2002). Toward a dialogic theory of public relations. Public Relations Review, 28(1), 21-37.

Kim, S., Choi, M., Reber, B., \& Kim D. (2014). Tracking public relations scholarship trends: Using semantic network analysis on PR Journals from 1975 to 2011. Public Relations Review, 40(1), 116118. 
King, C. (2010). Emergent communication strategies. International Journal of Strategic Communication, 4(1), 19-38.

Klein, M. (2007, December 31). The MIT Collaboratorium: Enabling effective large-scale deliberation for complex problems (Working Paper 4679-08). Cambridge MA: MIT Sloan School of Management. Retrieved from http://ssrn.com/abstract=1085295

Kluger, A. (2012). I'm all ears: Improving your organization through active listening. Melbourne, Vic: University of Melbourne. Retrieved from http://upclose.unimelb.edu.au/episode/186-i-m-all-earsimproving-your-organization-through-active-listening\#transcription

Kompridis, N. (2011). Receptivity, possibility, and democratic politics. Ethics and Global Politics, 4(4), 255-272.

Lacey, K. (2013). Listening publics: The politics and experience of listening in the media age. Malden, MA and Cambridge, UK: Wiley Blackwell/Polity.

Ledingham, J., \& Bruning, S. (1998). Relationship management and public relations: Dimensions of an organisation-public relationship. Public Relations Review, 24(1), 55-65.

Ledingham, J., \& Bruning, S. (Eds.). (2000). Public relations as relationship management: A relational approach to the study and practice of public relations. Mahwah, NJ: Lawrence Erlbaum.

Lee, M. (2012). The president's listening post: Nixon's failed experiment in government public relations. Public Relations Review, 38(1), 22-31.

Leite, E. (2015, January 19). Why trust matters in business. Address to the World Economic Forum, Davos-Klosters, Switzerland. Retrieved from https://agenda.weforum.org/2015/01/why-trust-mattersin-business

L'Etang, J. (2008). Public relations: Concepts, practice and critique. London and Thousand Oaks, CA: Sage.

Lincoln, Y., \& Guba, E. (1985). Naturalistic inquiry. Beverly Hills, CA: Sage.

Lipari, L. (2010). Listening, thinking, being. Communication Theory, 20(3), 348-362.

Littlejohn, S., \& Foss, K. (2008). Theories of human communication (9th ed.). Belmont, CA: ThomsonWadsworth.

Lundsteen, S. (1979). Listening: Its impact on language and the other language arts. Urbana, IL: ERIC Clearing House on Reading and Communication Skills.

Macey, W., \& Schneider, B. (2008). The meaning of employee engagement. Industrial and Organizational Psychology, 1(1), 3-30.

Macnamara, J. (2014). The 21st century media (r)evolution: Emergent communication practices. New York, NY: Peter Lang.

Mastercard. (2014). The Engagement Bureau, The Mastercard Conversation Suite. Retrieved from http://newsroom.mastercard.com/videos/mastercard-conversation-suite-video

Miles, M., \& Huberman, M. (1994). Qualitative data analysis. Thousand Oaks, CA: Sage.

Murphy, P. (1991). Limits of symmetry. In J. Grunig \& L. Grunig (Eds.), Public relations research annual, 3 (pp. 115-131). Hillsdale, NJ: Lawrence Erlbaum.

Murphy, P. (2011, May). Contextual distortion: Strategic communication vs. the networked nature of everything. Paper presented at the International Communication Association 2011 pre-conference, Strategic Communication: A Concept at the Center of Applied Communications, Boston, MA.

Neuman, W. (2006). Social research methods: Qualitative and quantitative approaches (6th ed.). Boston, MA: Pearson Education.

Ovaitt, F. (2008, November 3). Is public engagement the future of public relations? Gainesville, FL: Institute for Public Relations, blog post. Retrieved from http://www.instituteforpr.org/is-publicengagement-the-future-of-public-relations

Patton, M. (2002). Qualitative research and evaluation methods (3rd ed.). Thousand Oaks, CA: Sage.

Pelias, R., \& VanOosting, J. (1987). A paradigm for performance studies. Quarterly Journal of Speech, 73(2), 219-231.

Penman, R., \& Turnbull, S. (2012). From listening ... to the dialogic realities of participatory democracy. Continuum: Journal of Media \& Cultural Studies, 26(1), 61-72. 
Pieczka, M. (1996). Paradigms, systems theory and public relations. In J. L’Etang \& M. Pieczka (Eds.), Critical perspectives in public relations (pp. 124-156). London, UK: International Thomson Business Press.

Pieczka, M. (2006). Paradigms, systems theory and public relations. In J. L’Etang \& M. Pieczka (Eds.), Public relations: Critical debates and contemporary practice (pp. 331-358). Mahwah, NJ: Lawrence Erlbaum.

Pieczka, M. (2011). Public relations as dialogic expertise? Journal of Communication Management, 15(2), 108-124.

Porter, L. (2010). Communicating for the good of the state: A post-symmetrical polemic on persuasion in ethical public relations. Public Relations Review, 36(20, 127-133.

Punch, K. (1998). Introduction to social research: Quantitative and qualitative approaches. London, UK: Sage.

Purdy, M. (2004, April). Qualitative research: Critical for understanding listening. Paper presented at the International Listening Association Conference, Fort Meyers, FL.

Purdy, M., \& Borisoff, D. (1997). Listening in everyday life: A personal and professional approach (2nd ed.). Lanham, MA: University of America Press.

Rhoades. L., Eisenberger, R., \& Armeli, S. (2001). Affective commitment to the organization: The contribution of perceived organisational support. Journal of Applied Psychology, 86, 825-836.

Schramm, W. (1971). The nature of communication between humans. In W. Schramm \& D. Roberts (Eds.), The purpose and effects of mass communication (rev. ed., pp. 1-53). Urbana, IL: University of Illinois Press.

Shannon, C., \& Weaver, W. (1949). The mathematical theory of communication. Urbana, IL: University of Illinois.

Shenton, A. (2004). Strategies for ensuring trustworthiness in qualitative research projects. Education for Information, 22(2), 63-75.

Shoemaker, P., \& Reese, S. (1996). Mediating the message: Theories of influences on mass media content (2nd ed.). White Plains, NY: Longman.

Silverstone, R. (2007). Media and morality: On the rise of the mediapolis. Cambridge, UK: Polity.

Sonnenfeld, J. (1982). Public affairs execs: Orators or communicators? Public Relations Review, 8(3), 316.

Spicer, C. (2007). Collaborative advocacy and the creation of trust: Toward an understanding of stakeholder claims and risks. In E. Toth (Ed.), The future of excellence in public relations and communication management: Challenges for the next generation (pp. 27-40). Mahwah, NJ: Lawrence Erlbaum.

Sriramesh, K. (2009). Introduction. In K. Sriramesh \& D. Verčič (Eds.), The global public relations handbook: Theory, research, and practice (rev. ed., pp. xxxii-xxxvii). Abingdon, UK: Routledge.

Stake, R. (2008). Qualitative case studies. In N. Denzin \& Y. Lincoln (Eds.), The SAGE handbook of qualitative research (3rd ed., pp. 119-149). London, UK and Thousand Oaks, CA: Sage.

Stationery Office. (2013). Report of the Mid Staffordshire NHS Foundation Trust Public Inquiry. Retrieved from http://www.midstaffspublicinquiry.com/sites/default/files/report/Executive\%20summary.pdf

Strauss, A., \& Corbin, J. (1990). Basics of qualitative research: Grounded theory procedures and techniques. Newbury Park, CA: Sage.

Tashakkori, A., \& Teddlie, C. (2003). Handbook of mixed methods in social and behavioral research. Thousand Oaks, CA: Sage.

Taylor, M., \& Kent, M. (2014). Dialogic engagement: Clarifying foundational concepts. Journal of Public Relations Research, 26(5), 384-398.

Tench, R., \& Yeomans, L. (2009). Exploring public relations (2nd ed.). Harlow, UK: Prentice HallPearson Education.

Theunessin, P., \& Noordin, W. (2012). Revisiting the concept of dialogue in public relations. Public Relations Review, 38, 5-13.

Tilley, E. (2015). The paradoxes of organizational power and public relations ethics: Insights from a feminist discourse analysis. Public Relations Inquiry, 4(1), 79-98. 
Toth, E. (Ed.). (2007). The future of excellence in public relations and communication management: Challenges for the next generation. Mahwah, NJ: Lawrence Erlbaum.

van Ruler, B., \& Verčič, D. (2005). Reflective communication management, future ways for public relations research. In P. Kalbfleisch (Ed.), Communication yearbook 29 (pp. 238-273). Mahwah, NJ: Lawrence Erlbaum.

Waks, L. (2010). Two types of interpersonal listening. Teachers College Record, 112(11), 2743-2762.

Weiner, M. (2012, September). Showcase to the social media world. Kommunikations Manager, 3, pp. 6 10.

Wilcox, D., \& Cameron, G. (2010). Public relations: Strategies and tactics (9th ed.). Boston, MA: Allyn \& Bacon.

Wolvin, A., \& Coakley, G. (1996). Listening (5th ed.). Madison, WI: Brown \& Benchmark.

Yang, S., Kang, M., \& Cha, H. (2015). A study on dialogic communication, trust, and distrust: Testing a scale for measuring organization-public dialogic communication (OPDC). Journal of Public Relations Research, 27(2), 175-192.

Yin, R. (2009). Case study research: Design and methods (4th ed.). Thousand Oaks, CA: Sage.

\section{Published reference:}

Macnamara J. (2016). Organizational listening: Addressing a major gap in public relations theory and practice. Journal of Public Relations Research, vol. 28, no. 3-4, pp. 146-169. doi: http://dx.doi.org/10.1080/1062726X.2016.1228064

Jim Macnamara PhD is Professor of Public Communication at the University of Technology Sydney, a position he took up in 2007 after a 30-year professional career spanning journalism, public relations and media research. He is the author of 15 books including The 21 $1^{\text {st }}$ Century Media (R)evolution: Emergent Communication Practices (Peter Lang, New York, 2014) and Organizational Listening: The Missing Essential in Public Communication (Peter Lang, New York, 2016).

1 Listening in this context refers to listening as defined in the section 'Defining listening'. It does not refer specifically to dialogic listening, which is described as an interplay between speaking and active listening (Dobson, 2014; Waks, 2011), although dialogic listening meets most of the criteria identified for ethical effective listening.

2 The Organizational Listening Project is examining 10 public communication functions: audience and social research; customer relations; social media; public consultation; marketing communication; corporate communication; public relations; organizational (internal) communication; government communication; and political communication.

3 The term 'press releases' was extensively used by corporate and government PR practitioners interviewed in this study, even though 'media releases' or 'news releases' are more inclusive terms. 